\title{
Map of total phosphorus content in native soils of Brazil
}

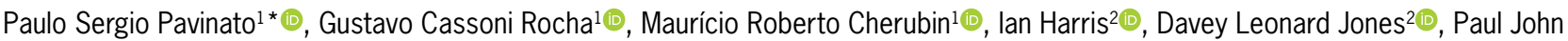 \\ Anthony Withers ${ }^{3}$
}

\author{
'Universidade de São Paulo/ESALQ, Av. Pádua Dias, 11 - \\ 13418-900 - Piracicaba, SP - Brasil. \\ 2Bangor University/School of Natural Sciences, LL57 2UW - \\ Bangor, Gwynedd - UK. \\ ${ }^{3}$ Lancaster University/Lancaster Environment Centre, LA1 \\ 4YQ - Lancaster - UK. \\ *Corresponding author <pavinato@usp.br>
}

Edited by: Paulo Cesar Sentelhas

Received March 24, 2020

Accepted June 23, 2020

\begin{abstract}
Knowledge of the distribution of total phosphorus $(\mathrm{P})$ content in native soils provides information on the management of ecosystem, land capability for agriculture, environmental quality, and biodiversity conservation. We mapped the spatial distribution of total $P$ concentrations in topsoils $(0-30 \mathrm{~cm}$ ) of uncultivated (native) areas in Brazil. We obtained data on native total $P$ of the southern, south-eastern, and north-eastern regions from reports of exploratory projects developed between 1960s and 1970s by EMBRAPA and by the RADAM Brazil Project. We estimated data from the central-western and northern regions from the relationship between total $\mathrm{P}$ and soil properties (Fe, Al, $\mathrm{C}$ and clay content), based on the RADAM Brazil Project. Soil total $\mathrm{P}$ varied widely $\left(<25\right.$ to $>500 \mathrm{mg} \mathrm{kg}^{-1}$ ) in all regions in Brazil. Higher concentrations (> $500 \mathrm{mg} \mathrm{kg}^{-1}$ ) were observed in southern region compared to most of the rest of the country ( $<200 \mathrm{mg} \mathrm{kg}^{-1}$ ), while the Cerrado (Central), Amazon (North) and Caatinga (Northeast) biomes are very poor in total $P$. This first national native soil total $P$ map provides a valuable baseline for understanding the historical patterns of agriculture expansion in Brazil. It allows quantifying the effect of agriculture expansion and future cropping systems on soil available $P$ content and legacy $\mathrm{P}$, targeting regional soil-crop specific strategies for optimization of ecosystem services, and mitigating potential environmental risk due to $\mathrm{P}$ transference to water bodies.
\end{abstract}

Keywords: soil native $\mathrm{P}$, legacy $\mathrm{P}$, soil total $\mathrm{P}$, agriculture expansion

\section{Introduction}

Phosphorus $(\mathrm{P})$ is the most used nutrient in liming for plant growth in Brazilian tropical soils (Novais and Smyth, 1999; Roy et al., 2016). Overall, total P content in Brazilian soils range from 50 to over $1800 \mathrm{mg} \mathrm{kg}^{-1}$ (mean $300-350 \mathrm{mg} \mathrm{kg}^{-1}$ ); however, only a very small amount of this $\mathrm{P}$ is readily available for plants. In most regions in Brazil, there is predominance of highly weathered soils (Santos et al., 2018), characterized as high-P fixing soils, due to strong $\mathrm{P}$ adsorption of 1:1 clay minerals (e.g., kaolinite) and iron (Fe) and aluminium (Al) oxides (Novais and Smyth, 1999). In addition, a substantial fraction of total $\mathrm{P}(30-65 \%)$ is present in organic compounds, which can vary from readily available (labile) to non-available (non-labile) for plants (Turner et al., 2002; Condron et al., 2005; Shen et al., 2011). Therefore, total P content is expected to be closely related to the contents of clay, oxides (Fe and $\mathrm{Al})$, and organic matter $(\mathrm{OM})$ in soils.

Knowledge of the spatial variation and distribution of total $\mathrm{P}$ content in native soils may help increase agricultural productivity potential, environmental quality, and biodiversity conservation (Rossel and Bui, 2016, Delmas et al., 2015; Matos-Moreira et al., 2017). Maps of total $\mathrm{P}$ in native soils can foster regional and/ global biogeochemistry models by providing initial estimates of the soil $\mathrm{P}$ that can be potentially mobilized for plant uptake and by microbes (Yang et al., 2013). For instance, Yang et al. (2014) presented a global map of naturally occurring soil total $\mathrm{P}$ at 0.5 -degree spatial resolution. More recently, detailed maps of soil total $\mathrm{P}$ for managed land have been refined for many countries, namely Australia (Rossel and Bui, 2016), France (Delmas et al., 2015; Matos-Moreira et al., 2017), and the United States (Jarvie et al., 2015). Brazil currently does not have a map of national soil total $\mathrm{P}$. Thus, we mapped the spatial distribution of soil total $\mathrm{P}$ in the topsoil (0-30 $\mathrm{cm}$ ) of uncultivated (native) areas of Brazil for a better understanding of patterns of past agricultural expansion, for quantifying rates of soil $\mathrm{P}$ build-up associated to intensive farming systems, and for optimizing soil-crop specific strategies for sustainable land management with minimal environmental impact.

\section{Material and Methods}

Original total $\mathrm{P}$ contents in the surface $(0-30 \mathrm{~cm})$ of Brazilian soils under native vegetation were obtained from reports of exploratory projects developed for the 1960s to 1970s by the Brazilian Agricultural Research Corporation (EMBRAPA) and by the RADAM Brazil Project developed by the Brazilian Ministry of Mining and Energy (available soil profile data at https:// biblioteca.ibge.gov.br/visualizacao/livros/liv24027.pdf). These reports provided 1,593 soil sampling points with measured concentrations of total $\mathrm{P}$ (expressed originally in $\left.\mathrm{P}_{2} \mathrm{O}_{5}\right)$, iron oxide $\left(\mathrm{Fe}_{2} \mathrm{O}_{3}\right)$, aluminium oxide $\left(\mathrm{Al}_{2} \mathrm{O}_{3}\right)$, clay and carbon $(\mathrm{C})$ content. However, these data were mainly obtained from the southern, south-eastern, and north-eastern regions of Brazil. There was lack of total $\mathrm{P}$ data for the central-western and northern regions (Figure 1). For all sampling points, total $\mathrm{P}$ was measured by concentrated sulfuric acid digestion.

Other 3,724 soil sampling points identified by the RADAM Brazil Project and other regional surveys (Cooper et al., 2005) provided data on $\mathrm{Fe}_{2} \mathrm{O}_{3}, \mathrm{Al}_{2} \mathrm{O}_{3}$, clay 


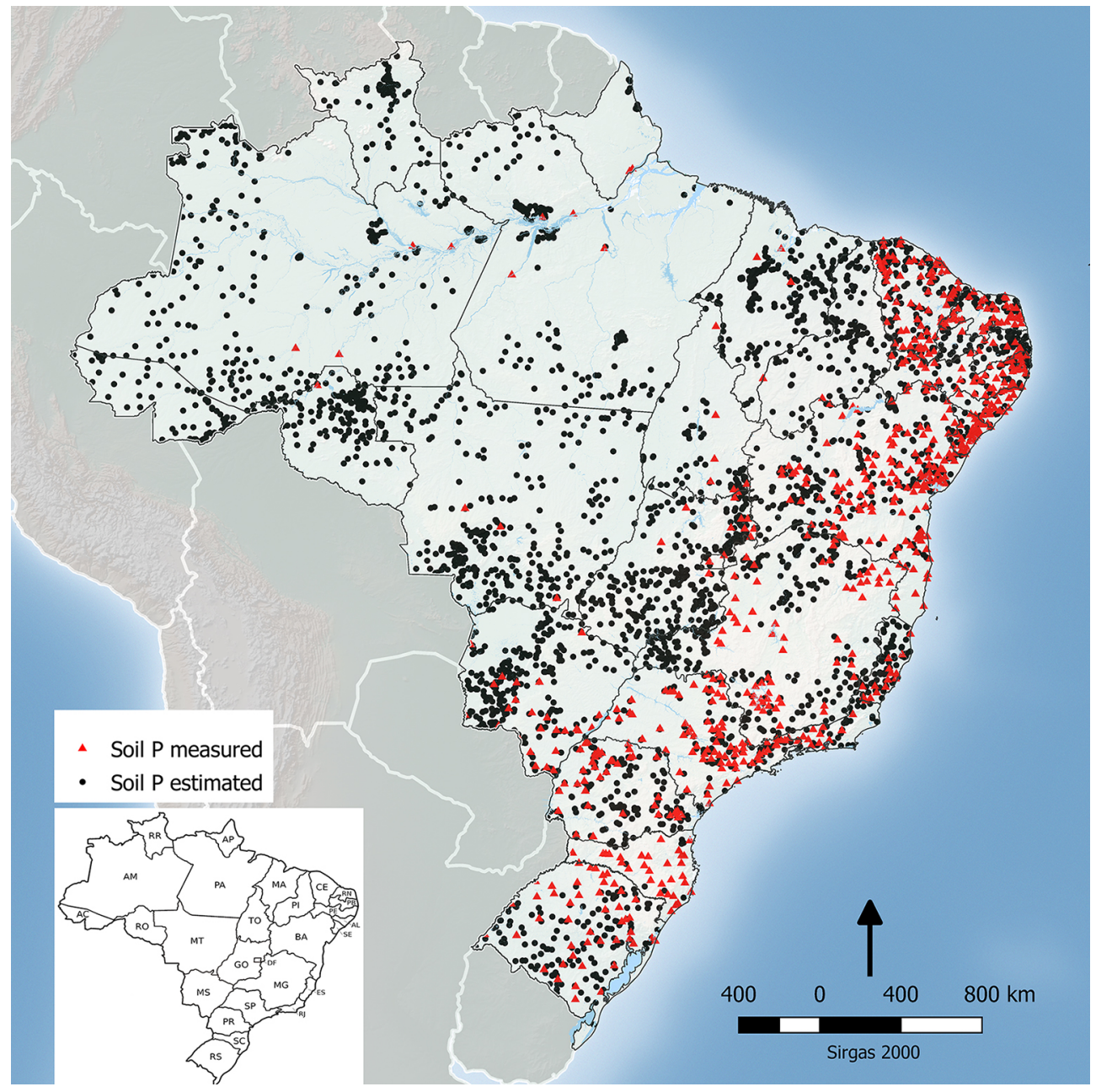

Figure 1 - Location of the sampling points of topsoil $(0-30 \mathrm{~cm})$ total $P$ content in Brazil. Measured $P$ values are represented by red triangles and estimated $\mathrm{P}$ values by stepwise regression by black points. The inset details the location of individual states in Brazil.

and $\mathrm{C}$ contents, but not on total $\mathrm{P}$. For these additional sampling points, total $\mathrm{P}$ contents were estimated using the STEPWISE multiple linear regression analysis in SAS (Statistical Analysis System, version 9.4) considering the clay content, $\mathrm{C}$ content, $\mathrm{Fe}_{2} \mathrm{O}_{3}, \mathrm{Al}_{2} \mathrm{O}_{3}$ and $\mathrm{Fe}_{2} \mathrm{O}_{3}+\mathrm{Al}_{2} \mathrm{O}_{3}$ contents, as explanatory variables, all expressed in $\mathrm{g} \mathrm{kg}^{-1}$. After discarding the outliers (88 points), the best fit was obtained by Equation 1:

$\mathrm{P}_{\text {total }}=59.25+(0.0639$ clay $)+(14.8354 \mathrm{C})+\left(25.1793 \mathrm{Fe}_{2} \mathrm{O}_{3}\right)-$ $\left(1.1199\left(\mathrm{Fe}_{2} \mathrm{O}_{3}+\mathrm{Al}_{2} \mathrm{O}_{3}\right)\right)$,

(Pr > F of 0.0001), which gave a correlation coefficient $\left(R^{2}\right)$ between measured and estimated values of 0.68 (Figure 2). A similar dependency of total $\mathrm{P}$ on soil retention capacity was used previously to generate maps of soil total P in other countries (e.g. Delmas et al., 2015). In total, we obtained and used 5,317 points of measured and estimated values of native soil total $\mathrm{P}$ to build a map of their spatial distribution (Figure 1).

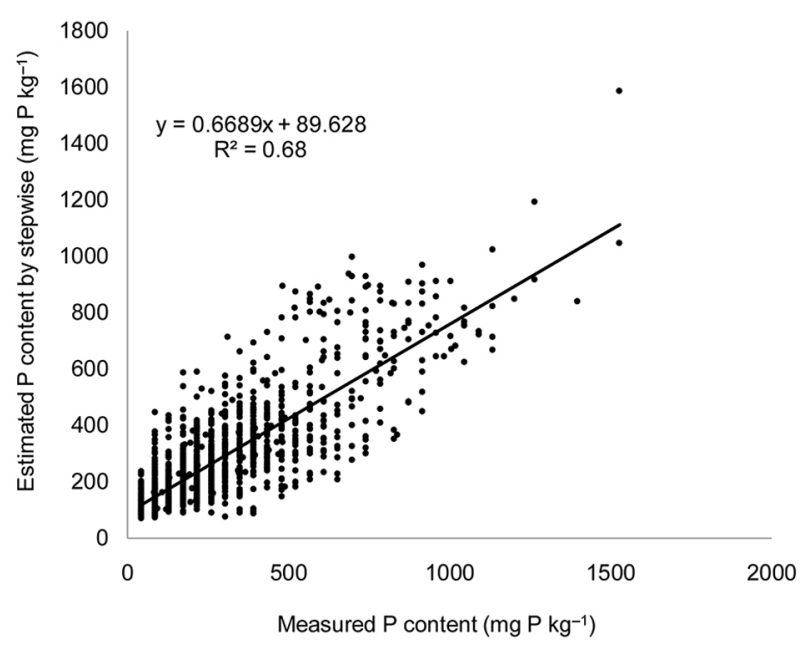

Figure 2 - Estimated total $P$ content by stepwise versus measured total $\mathrm{P}$ content in the topsoil $(0-30 \mathrm{~cm})$ all over Brazil. 
In step 1 for the establishment of spatial distribution of total native $\mathrm{P}$ content, measured $\mathrm{P}$ values were plotted onto the soil classification standard map established as the Brazilian Soil Classification System SiBCS (Santos et al., 2018). The RADAM survey database was standardized by soil order level, based on current SiBCS. Step 2 involved the spatialization of measured data on native total $\mathrm{P}$ harmonized according to the Boolean expression:

If $\mathrm{P}$ level $1<>$ null, then value $=\mathrm{P}$ level 1 else value $=$ P level 2 .

P level 1 - the priority level which required the field survey points to be matched with the boundaries of the soil map polygons, in the order level. If the measured data on soil class $\mathrm{P}$ coincides with the field survey (RADAM), the value of the field sample is considered.
If there were more than one coincident sample, the average was taken. This level was matched in $48 \%$ of the Brazilian territory. For P level 2, the measured values of native $\mathrm{P}$ interpolated by the Voronoi diagram method were matched to the boundaries of the soil classification polygons (SiBCS). Voronoi diagrams generate polygons from RADAM sampling points. For $\mathrm{P}$ level 1, where any $\mathrm{P}$ measured values were absent in the polygons, the mean value of $P$ level 2 was considered, resulting in the harmonized map of total native $\mathrm{P}$ (Figure 3 ).

\section{Results and Discussion}

The Brazilian territory presents large spatial variability in total $\mathrm{P}$ content in native soils, with values ranging from $<25$ to $>500 \mathrm{mg} \mathrm{kg}^{-1}$ (Figure 3). Higher values ( $>500 \mathrm{mg} \mathrm{kg}^{-1}$ ) were observed in southern Brazil, especially in western Paraná (PR), Santa Catarina (SC)

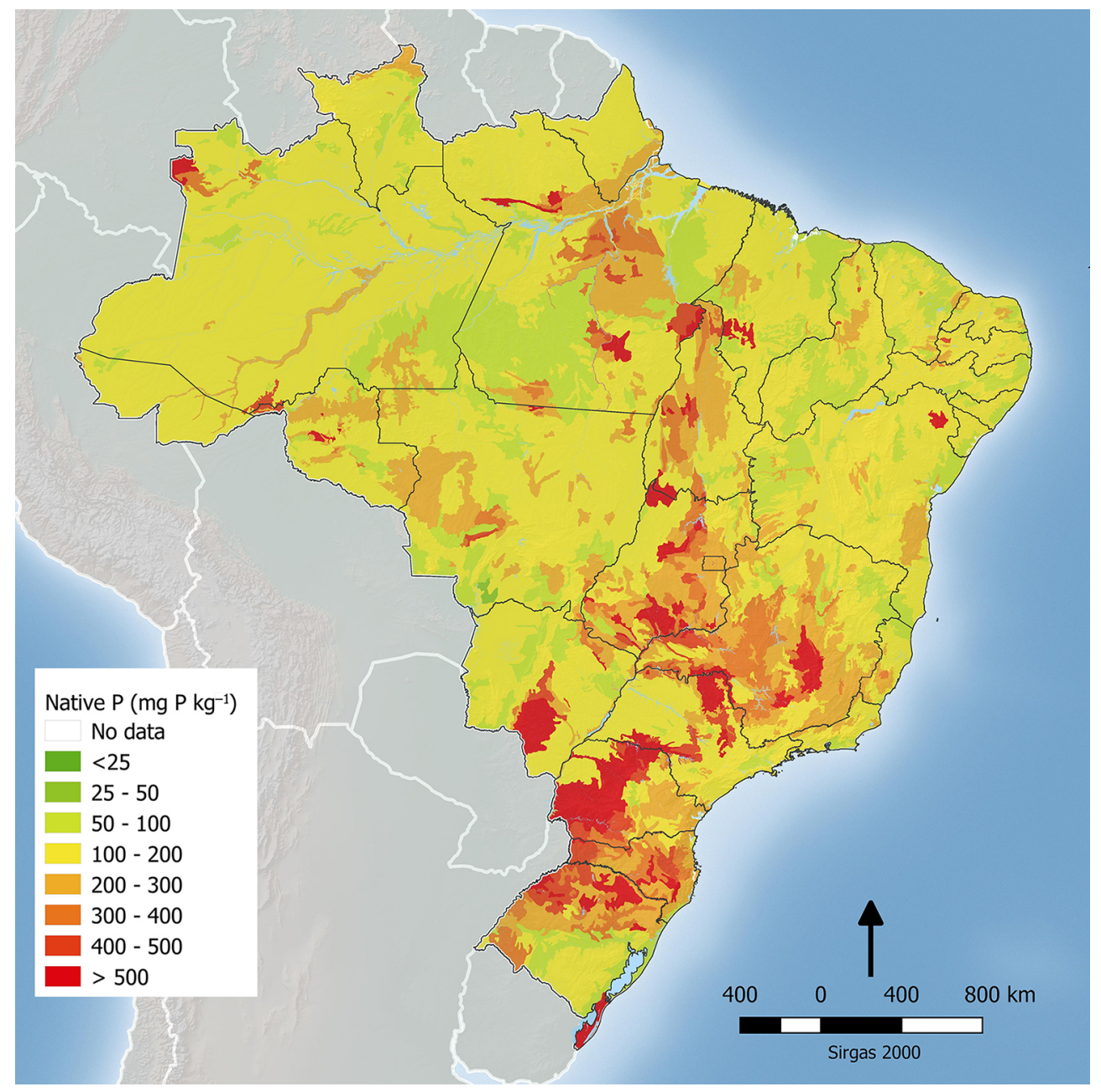

Figure 3 - Spatial distribution of native total P content $\left(\mathrm{mg} \mathrm{P} \mathrm{kg}^{-1}\right)$ in the surface layer $(0-30 \mathrm{~cm})$ of the soils across Brazil. The map was built based on measured $P$ values observed in reports from the 1960s to 1970s (EMBRAPA exploratory and RADAM Brazil projects) and estimated $P$ values after the stepwise regression analysis considering the contents of clay, carbon, and Fe/Al sesquioxides where measured $P$ values were not available. 
and northern Rio Grande do Sul (RS) States compared to most of the rest of the country (typically $<200 \mathrm{mg}$ $\mathrm{kg}^{-1}$. Higher contents of native $\mathrm{P}$ are predominantly found in Oxisols ("Latossolos" and "Nitossolos" - SiBCS, Santos et al., 2018) and Inceptisols ("Cambissolos" SiBCS) developed over P-rich apatitic parent material and containing high contents of clay, $\mathrm{Fe}$, and/or $\mathrm{Al}$, as well as a large capacity to adsorb P (Rodrigues et al., 2016). In addition, higher organic $C$ stocks in these soils (Bernoux et al., 2002) contribute to the accumulation of organic $\mathrm{P}$ forms, highly important for recycling $\mathrm{P}$ in non-agricultural environments without the input of mineral/organic fertilizers. Brazilian grain production (e.g. soybean, maize, and wheat) first started in the P-rich areas in the southern regions of the country in the early 1900s, when Europeans and their descendants (e.g., Italians, Germans, and Polish) migrated to Brazil to escape war and famine.

Moving north, part of states of São Paulo (SP), Minas Gerais (MG), Goiás (GO), and Tocantins (TO) have mostly intermediate total $\mathrm{P}$ contents $(200-400 \mathrm{mg}$ $\mathrm{kg}^{-1}$; however, with some specific hotspots containing more than $800 \mathrm{mg} \mathrm{kg}^{-1}$ (Figure 3). Soils in these states are also characterized by intermediate $\mathrm{C}$ stocks (Bernoux et al., 2002) and have expanded more rapidly to sugarcane and coffee production and livestock, from the early to the middle of 1900 s, with a the general expansion of grain production in the last two decades (Dias et al., 2016).

More recently, between the 1970s and 1990s, the agriculture frontier expanded toward the Cerrado biome (Brazilian Savanna), in the central-western region (e.g., states of Mato Grosso do Sul (MS), Mato Grosso (MT) and Goiás (GO) and their borders with north-eastern and northern regions (e.g. states of Tocantins (TO), Pará (PA), Bahia (BA), Piauí (PI) and Maranhão (MA)). At this time, agriculture was established on chemically poor soils with high acidity levels, very low contents of total $\mathrm{P}\left(<200 \mathrm{mg} \mathrm{kg}^{-1}\right)$, and negligible available $\mathrm{P}$ levels $\mid<1$ $\mathrm{mg} \mathrm{kg}{ }^{-1}$ Mehlich-1), besides other nutrient limitations. These areas require high inputs of lime, gypsum, and fertilizers to develop initial crop production (Roy et al., 2017). Moreover, the Cerrado biome currently remains the main frontier region for Brazilian cropland expansion (Dias et al., 2016).

The lowest contents of soil total P (between 50 and $200 \mathrm{mg} \mathrm{kg}^{-1}$ ) are observed in MT, MS (excluding Pantanal region) and other states of the northern and north-eastern regions of Brazil (Figure 3). Soils in these regions are predominantly Ultisols, Alfisols (Argissolos - SiBCS) and Psamment/Entisols (Neossolos Quartzarênicos - SiBCS) developed from base-poor arenitic parent materials (e.g in the Amazon basin; Bigarella, 1973), with low clay contents and C stocks (Bernoux et al., 2002), and are more susceptible to $\mathrm{P}$ removal (erosion/runoff). Agricultural intensification in these areas in recent decades, and further expansion predicted for the next one (MAPA, 2016), has required efficient and sustainable fertilizer/soil/crop management practices. For example, application of fertilizer in the seed furrow, use of more controlled released $\mathrm{P}$ fertilizers, no-tillage management, and intercropping with cover crops, to minimize both $\mathrm{P}$ loss by runoff/erosion and/or soil $\mathrm{P}$ adsorption. A challenge for future agriculture is sustaining high crop yields without heavy applications of fertilizers in these regions.

Our mapping of native soil $\mathrm{P}$ across Brazil indicated that large-scale grain production started in the early 1900s on more naturally fertile clayey soils in southern/south-eastern regions with higher OM levels and total $\mathrm{P}$ content. Increasing demand for food, fiber, and energy then led to further expansion on the P-depleted poorer soils of the centralwestern, northern, and north-eastern Brazil in the late 1980s, demanding high inputs of fertilizers and other amendments to improve the soil capacity for crop production. The remaining areas of potential agricultural expansion are also on these poorer soils and require a rigorous soil management, especially to control soil erosion, reduce soil acidification, and increase nutrient availability in order to avoid adverse environmental impacts.

Moreover, this first national map of topsoil total $\mathrm{P}$ provides pioneering information that can used as a baseline for quantifying the accumulation of legacy soil $\mathrm{P}$ arising from agricultural expansion. In addition, it can help to guide land suitability mapping, sustainable land use, and soil P management that ensure profitable agricultural productivity, mitigating environmental risks that have affected other countries. For soil scientists, this dataset may be useful for modelling soil $\mathrm{P}$ dynamics, as well as potential soil P losses by runoff/ erosion, particularly in native vegetation areas where fertilizer is not applied. Finally, as a base resource, the total P map also provides material for soil fertility studies and knowledge dissemination on P management in Brazilian soils.

\section{Acknowledgments}

Thanks to the São Paulo Research Foundation (FAPESP), grant $\mathrm{n}^{\circ}$ 2017/04186-2, for the postdoc scholarship of the first author. Thanks to Vinicius de M. Benites for the collaboration in supplying partial data for maps estimate.

\section{Authors' Contributions}

Conceptualization: Pavinato, P.S.; Jones, D.L.; Withers, P.J.A. Data acquisition: Pavinato, P.S. Data analysis: Pavinato, P.S.; Cherubin, M.R; Rocha, G.C.; Harris, I. Design of methodology: Pavinato, P.S.; Jones, D.L.; Withers, P.J.A. Writing and editing: Pavinato, P.S.; Cherubin, M.R; Jones, D.L.; Withers, P.J.A. 


\section{References}

Bernoux, M.; Carvalho, M.C.S.; Volkoff, B.; Cerri, C.C. 2002. Brazil's soil carbon stocks. Soil Science Society of America Journal 66: 888-896.

Bigarella, J.J. 1973. Geology of the Amazon and Parnaiba basins. p. 25-86. In: Nairn, A.E.M.; Stehli, F.G., eds. The ocean basins and margins. New York, NY, USA.

Condron, L.M.; Turner, B.L.; Cade-Menun, B.J. 2005. Chemistry and dynamics of soil organic phosphorus. p. 87-121. In: Sims, J.T.; Sharpley, A.N., eds. Phosphorus: agriculture and the environment. Soil Science Society of America, Madison, WI, USA.

Cooper, M.; Mendes, L.M.S.; Silva, W.L.C.; Sparovek, G. 2005. A national soil profile database for Brazil available to international scientists. Soil Science Society of America Journal 69: 649-652.

Delmas, M.; Saby, N.; Arrouays, D.; Dupas, R.; Lemercier, B.; Pellerin, S.; Gascuel-Odoux, C. 2015. Explaining and mapping total phosphorus content in French topsoils. Soil Use \& Management 31: 259-269.

Dias, L.C.P.; Pimenta, F.M.; Santos, A.B.; Costa, M.H.; Ladle, R.J. 2016. Patterns of land use, extensification, and intensification of Brazilian agriculture. Global Change Biology 22: 2887-2903.

Jarvie, H.P.; Sharpley, A.N.; Flaten, D.; Kleinman, P.J.A.; Jerkins, A.; Simmons, T. 2015. The pivotal role of phosphorus in a resilient water-energy-food security nexus. Journal of Environmental Quality 44: 1049-1062.

Matos-Moreira, M.; Lemercier, B.; Dupas, R.; Michot, D.; Viaud, V.; Akkal-Corffini, N.; Louis, B.; Gascuel-Odoux, C. 2017. High-resolution mapping of soil phosphorus concentration in agricultural landscapes with readily available or detailed survey data. European Journal of Soil Science 68: 281-294.

Ministério da Agricultura, Pecuária e Abastecimento [MAPA]. 2016. Projections of Agribusiness Brazil 2015/16 to 2025/26: Long Term Predictions. Brasília, DF, Brazil.

Novais, R.F.; Smyth, T.J. 1999. Phosphorus in Soil and Plants in Tropical Conditions $=$ Fósforo em Solo e Planta em Condições Tropicais. Universidade Federal de Viçosa, Viçosa, MG, Brazil (in Portuguese).
Rodrigues, M.; Pavinato, P.S.; Withers, P.J.A.; Teles, A.P.B.; Herrera, W.F.B. 2016. Legacy phosphorus and no tillage agriculture in tropical oxisols of the Brazilian savanna. Science of The Total Environment 542: 1050-1061.

Rossel, R.A.V.; Bui, E.N. 2016. A new detailed map of total phosphorus stocks in Australian soil. Science of the Total Environment 542: 1040-1049.

Roy, E.D.; Willig, E.; Martinelli, L.A.; Richards, P.D.; Vazquez, F.F.; Pegorini, L.; Spera, S.A.; Porder, S. 2017. Soil phosphorus sorption capacity after three decades of intensive fertilization in Mato Grosso, Brazil. Agriculture, Ecosystems and Environment 249: 206-214.

Roy, E.D.; Richards, P.D.; Martinelli, L.A.; Coletta, L.D.; Lins, S.R.M.; Vazquez, F.F.; Willig, E.; Spera, S.A.; VanWey, L.K.; Porder, S. 2016. The phosphorus cost of agricultural intensification in the tropics. Nature Plants 43: 1-6.

Santos, H.G.; Jacomine, P.K.T.; Anjos, L.H.C.; Oliveira, V.A.; Lumbreras, J.F.; Coelho, M.R.; Almeida, J.A.; Araujo Filho, J.C.; Oliveira, J.B.; Cunha, T.J.F. 2018. Brazilian Soil Classification System. 5ed. Embrapa, Brasília, DF, Brazil.

Shen, J.; Yuan, L.; Zhang, J.; Li, H.; Bai, Z.; Chen, X.; Zhang, W.; Zhang, F. 2011. Phosphorus dynamics: from soil to plant. Plant Physiology 156: 997-1005.

Turner, B.L.; Papha'zy, M.J.; Haygarth, P.M.; McKelvie, I.D. 2002. Inositol phosphates in the environment. Philosophical Transactions of the Royal Society B: Biological Sciences 357: 449-469.

Yang, X.; Post, W.M.; Thornton, P.E.; Jain, A. 2013. The distribution of soil phosphorus for global biogeochemical modeling. Biogeosciences 10: 2525-2537.

Yang, X.; Post, W.M.; Thornton, P.E.; Jain, A. 2014. Global gridded soil phosphorus distribution maps at 0.5-degree resolution: data set. Oak Ridge National Laboratory, Oak Ridge, TN, USA. 